\title{
DETERMINANTS OF CUSTOMER PATRONAGE OF FAST FOOD OUTLETS IN BENIN CITY
}

\author{
UGO CHUKS OKOLIE ${ }^{1}$ \\ Department of Political Science, Delta State University
}

IDONGESIT DAVID UDOM ${ }^{2}$

Department of Vocational and Technical Education, University of Benin

\begin{abstract}
This study critically examined the factors influencing customer patronage of fast food outlets in Benin City. Specifically, the independent variables examined include quality of service delivery, brand image and price and how they relate to customer patronage. The study adopted survey research design. The population includes all customers that patronise fast food outlets in Benin City, Edo State. Fifty (50) respondents each were chosen in four fast food outlets namely: Mr. Biggs, Mat Ice, Kada Food and Omega Food to have a sample size of two hundred (200) out of which 188 questionnaires were found useable, amounting to $94 \%$. The data analyses were done using both descriptive and inferential statistics. All analyses were done using Statistical Package for Social Sciences (SPSS 22.0) software. The study revealed that there are positive and significant relationship between the independent variables (service quality and brand image) and customer patronage except price that showed negative and not significant relationship with customer patronage. Based on these findings, the study recommended that fast food operators should continue to maintain high quality service delivery that will enhance the brand image of selected fast food outlets.
\end{abstract}

Keywords: Nigeria, service quality, brand image, customer value, customer patronage, fast food outlets

\section{INTRODUCTION}

The contemporary fast food revolution essentially had its origins in the US in the mid 1950's and this style of catering has continued to grow there and to most of the rest of the world (Jones, Hillier, Sheers \& Clarke-Hill, 2002). Schlosser (2002) argue that fast food can be seen as a powerful symbol of globalisation and post-modern society and few countries of the world seem immune to its

\footnotetext{
Contact: Ugo Chuks Okolie, ugookolie3@gmail.com, Department of Political Science, Delta State University, Abraka, Nigeria.

2 Contact: Idongesit David Udom, idongesitudom@uniben.edu.ng, Department of Vocational and Technical Education, University of Benin, Benin City, Nigeria.
} 
apparent attractions. According to Salami and Ajobo (2012, p.75), "Nigerians were first introduced to fast foods within the context of what obtains in United African Company (UAC) when they opened MR. BIGGS restaurant in 1987.” However, long before then traditional fast foods had been in vogue and continue to be patronised. These include roasted plantain (bolie), roasted / fried yam (dundun), akara, suya meat (beef kebab), and fura de nono (local yogurt). Since the introduction of Mr. Biggs into the fast food industry, consumer acceptance of fast food has continued to increase. These include Tantalizers, Sweet Sensation, Tasty Fried Chicken, Chicken Republic, Mama Cass, Munchies, among others. Some of the fast food chains like Mr. Biggs, Tantalizers and Tasty Fried Chicken are now listed on the Nigerian Stock Exchange (Salami \& Ajobo, 2012). The latest big entrants are McDonalds and Kentucky Fried Chicken (KFC). Many of the fast foods have outlets in the major cities of Nigeria such as Abuja, Benin City, Port Harcourt, Ibadan, Calabar, Warri and Asaba (Salami \& Ajobo, 2012). The city of Lagos remains the headquarters of fast foods in Nigeria, although with the rapid urbanisation and expansion of the other cities it means that most expansion in the fast food industry will take place outside Lagos.

In many cities in Nigeria, one can find numerous fast food restaurants where most of the foods sold are usually snacks, burgers, fries, chicken, cola drinks, ice cream, fruit drinks and other foods that are high in fat, sodium and sugar (Ajala, 2006; Aladelokun, 2006). The growth of this business can be noted in the fact that the number of fast food eating establishments scattered all over major streets of big cities, increased in the past few years with different exotic and enticing names (Konwea, 2012). It is in line with this monumental growth of fast food outlets in Nigeria that this study seeks to unfold the factors that motivate customers to patronise them.

\section{Statement of the Research Problem}

In the agricultural lifestyle of the past, most people grew and prepared their own meal. People consume a greater number of fresh fruits, vegetables and grains and fewer amounts of salts, fats and refined sugar. Most of the foods now lined up in fast food chains bear little remembrance to the original farm product (Konwea, 2012). Medical Research Council found that most fast food is very dense in calories so that people need only a small amount to bump up their calorie intake. Most of these foods are highly processed, often stripped of key nutrients and the result of this is malnutrition. The World Health Organisation (2000) report revealed that more than one billion adults worldwide are overweight and at least 300 million people clinically obsessed. This was attributed to the consumption of junk or refined food. He therefore linked the alarming figures of obsessed people to the high preference for fast food and consumption of non-nutritious diets (Adeniyi, 2005).

Adeniyi (2004) reporting the remark of a nutrition experts about Nigeria pointed out that there are different nutritional diseases that are now plaguing 
the society. According to him nutrition experts have linked such diseases to abuse of certain foods. He further explained that diseases like diabetes, obesity are linked to high rate of sugar consumption as well as the craze for sugary foods both by the young and adults which are mostly sold in fast food outlets. The tastes and needs of consumers are dynamic, implying that every brand should constantly seek ways to offer freshness in order to remain relevant in the market place. The fast food industry is no longer divided into clear-cut segments since the products and services offered do sometimes overlap (Salami \& Ajobo, 2012). Therefore, the way and manner services are rendered by fast food outlets are critical to gaining competitive edge. Any service provider that seeks to enjoy competitive edge must respond to customer needs so as to promote satisfaction and secure continuous customer patronage. The intensity of competition has created the need for fast food enterprises to seek way of serving their customers better so as to win their patronage.

There has been very little academic research on the fast food sector in the developing countries, so little is known about the fast food consumer in these countries (Ibrahim \& Vignoli, 2005). In order to identify patterns of consumer patronage in the fast food market, a study of this nature is needed. Consequently, this study seeks to critically examine the extent to which service quality, brand image, customer value (price) and customers' demographic characteristics determine their patronage of fast food outlets in Benin City.

\section{RESEARCH QUESTIONS}

Deriving from the stated problem, this study formulated the following questions:

1. Does the quality of service render by fast food outlets significantly affect customer patronage?

2. What is the influence of brand image on customer patronage of fast food outlets?

3. Is there any significant relationship between customer value (price) and customer patronage of fast food outlets?

\section{OBJECTIVES OF THE STUDY}

The main objective of this study is to critically examine the determinants of customer patronage of fast food outlets in Benin City. Specifically, the study seeks, to:

1. Determine whether the quality of service render by fast food outlets significantly affect customer patronage;

2. Ascertain the influence of brand image on customer patronage of fast food outlets; and

3. Examine the relationship between customer value (price) and customer patronage of fast food outlets. 


\section{RESEARCH HYPOTHESES}

In line with the research questions and objectives, this study seeks to test the following null hypotheses:

1. Quality of service render by fast food outlets does not significantly affect customer patronage.

2. There is no significant relationship between brand image and customer patronage of fast food outlets.

3. There is no significant relationship between customer value (price) and customer patronage of fast food outlets.

\section{LITERATURE REVIEW}

\section{Overview of Fast Food Industry and its Growth in Nigeria}

A fast food restaurant also known as a Quick Service Restaurant (QSR) within the industry itself is a specific type of restaurant characterized both by the fast cooking and by minimal table service. Food served in fast food restaurants are cooked in bulk in advance and kept hot, is finished and packaged to order and is usually available or ready to take away, even though seating may be provided. According to Salami and Ajobo (2012), modern history of fast foods in America dated back to July 7, 1912 with the opening of a fast food restaurant called the Automat in New York. The Automat was a cafeteria with its prepared foods behind small glass windows and coin-operated slots. The company also popularized the notion of "take-out" food, with their slogan "less work for mother". The American company White castle is generally credited with opening the second fast-food outlet in Wichita, Kansas in 1921. Most historians state that A \& W was the first fast food restaurant which opened in 1919 (Grass, 1977). By 1961 Ray Krock bought out the McDonald brothers and created what is now the modern McDonald's corporation. One of his major business strategies was to promote cleanliness of his restaurants to the growing groups of Americans that had become aware of food safety issues. Fast food has generally been designed to be eaten "on-the-go" and often does not require traditional cutlery and is eaten as a finger food. Fast food outlets have become popular with consumers for several reasons. One is that through economics of scale in purchasing and producing food, these companies can deliver food to consumers at a very low cost. According to the Bureau of Educational and Cultural Affairs (http://exchanges.State.gov) although some people dislike fast food for its predictability, it can be reassuring to a hungry person in a hurry or far from home.

In his best-selling 2001 book Fast Food Nation, Schlosser (2001) levelled a broad, socio-economic critic against the fast food industry, documenting how fast food rose from small, family-run businesses (like McDonald brothers' hamburger joint) into large, multinational corporate juggernauts whose economies of scale radically transformed agriculture, meat processing, and labour markets in the late 
$20^{\text {th }}$ century. He argues further that while the innovations of fast food industry gave Americans more and cheaper dining options, it has come at the price of destroying the environment, economy, and small-town communities of rural America while shielding consumers from the real costs of their convenient meals, both in terms of health and the broader impact of large-scale food production and processing on workers, animals and land.

Because Nigeria is one of the fastest growing economy in the world, coupled with what may be described as emerging acculturation, more fast food restaurants are being established even on smaller scale. According to Salami and Ajobo (2012), the expansion in the fast food industry may be attributed to the following: increasing urban migration which affect the younger population who are also more receptive to the fast food concept; increasing Western acculturalization among the populace; the increasing affluence among the people; the changing life styles as indicated by the increasing belief that eating out is part of leisure; the perception among the working class singles (male and female) that fast food is cheaper and perhaps more efficient on their time; the changing demographic composition of the workplace as more women are employed at different levels of the economy; pressure of work and other social activities leave little room for cooking at home; and the expansion of fast food menus to incorporate indigenous dishes provide prospective customers a desired alternative to the Western meals, among others.

\section{Concept of Customer Patronage}

The customer is as old as business. The sole purpose of every business is to 'Create Customer' (Drucker, 1973). Drucker (1973) opined that the only economic and social justification for the existence of any business is to create customer satisfaction. The importance of the customer and customer patronage per se is so profound. It includes financial and non-financial dimensions. Many studies have been done on what influences or impacts on level of customer patronage. They include firm's capability, product or services attributes, economic situation, political forces, social and psychological factors, situational, competition, marketing mix programs (Ogwo \& Igwe, 2012; Schiffman \& Kanuk 2009). Experience indicates that defining and measuring patronage is extremely difficult. Attitude and actual usage patronages have been used as measures of customer patronages. Dick and Basu (1994) precisely suggest that favourable attitude and repeat purchase were required to define patronage. Intention to use is defined as a specific desire to continue relationship with a service provider (Czepiel \& Culmore, 1987). In measuring repurchase retention; surveys are usually obtained from existing customers by assessing their predisposition to buy the same brand, product or service from the same organisation (Ogbeide \& Agbadudu, 2015).

Attitudinal measures have an advantage over behavioural measures (actual or repeat patronage) in that they can provide greater understanding of the factors associated with the development and modification of patronage (Oliva, Oliver \& MacMilian, 1992). Ajzen and Fishbein (1980) argue that attitudes are functionally 
related to behavioural intentions, which predict behaviour. A person's intention to behave in a certain way is contingent upon the attitude toward performing the behaviour in question and the social pressure on him/her to behave in that way (subjective norm). This suggests that attitudes and subjective norms differ according to the person involved and behavioural context.

Theory of Planned Behaviour (TPB), which is an extension of Theory of Reasoned Action (TRA), has introduced another factor that affects behavioural intention, which is the perceived behavioural control. Control beliefs and perceived power are the main construct of perceived behavioural control. Consumers vary in their commitment to attitude; the degree of commitment relates to their level of involvement with the attitude object. This commitment ranges from inertia to a strong emotional passion. Commitment might be based on customers' intentions as want, expectation, plans for the future and even emotional attachment to a product. We concentrated more in this study on customer's intention to patronise a product in the future and recommend such to friends. This is in line with Tafamel and Oshodin (2015, p. 130) submission that "if customer is satisfied, he/she will be more likely to have willingness to buy again, namely repeating purchase or recommending others to buy."

In the behavioural attitude, behavioural patronage or usage measures are based on observable responses to, object, promotional stimuli-repeat purchases, and number of purchase, usage, behaviour, then attitude rather towards the product or brand (Schiffman \& Kanuk, 2009). Critically, it neglects the psychological aspect of patronage. The theory of reasoned action as expanded from Fishbein's model aims to measure and support behavioural intention, recognising that certain uncontrollable factors limit our ability to predict the future with 100 percent accuracy.

\section{Review of Studies on Customer Patronage}

In this section, the identified factors that can influence customer patronage are conceptually and empirically reviewed. The factors are: service quality, brand image and customer value (price).

\section{Service Quality and Customer Patronage}

The term "service" has been defined severally by different authors. Inegbenebor (2006) defines service an as intangible benefit provided to individuals, businesses, government establishments and other organisations through the performance of a variety of activities or the provision of physical facilities, product or activity for another's use. A service is any act or performance that one party can offer to another that is essentially intangible and does not result in the ownership of anything. Its production may or may not be tied to a physical product (Kotler, 2003). According to Stanton, Etzel and Walker (1998) described services as identifiable, intangible activities that are the main object of a transaction designed to provide want-satisfaction to customers. Morden (1991) posits that service refers to those 
separately identifiable, but intangible activities that provide want-satisfaction for the sale of a product or another service. A service is an act or benefit that does not result in the customer owing anything. This definition expresses the central idea, but it is limited in that it does not sufficiently distinguish between the marketing of goods and services (Peter, 1998).

\section{Characteristics of Services}

There are five important features of services. These features are explained as follows:

Intangibility: A service is said to be intangible because it had no physical properties. It cannot be seen, felt, tasted or tested before purchasing it. Because it is intangible, one can only experience it after purchasing it, by seeking the opinion of those who have used or experienced it, or by deduction from the physical items used in producing it. As a result of this, a company's promotional programmed must portray the benefits to be derived from the service rather than emphasizing the service itself. Ijewere (2008) outlines four promotional strategies that may be used to suggest services benefits which are as follows:

a. Visualisation: For example, most educational institutions depict the benefits of their school with adverts like book, biro, school children, and children's toys and so on.

b. Association: It is when the service is connected with a tangible good, person, object or place. For example NYSC, emblem depicts the Nigeria Flag and Unity torch.

c. Physical Representation: For example, restaurants, telephone companies, health centres etc. dress their services representatives in clean, distinctive uniforms to stress visibility, cleanliness and dependability.

d. Documentation: It is when service firms cite facts and figures in their advert to support their claims. For instance, Nigeria Television Authority (NTA) claims that millions of Nigerians view their programmes across the country.

Perishability: Perishability means that service cannot be stored or stored. A service cannot be stored the way physical products are stored awaiting consumption at a different time or location. Services are consumed as they are being created or provided. The services of a doctor or a nurse in a health centre are consumed by the patient and his/her relations as they are being provided. If the health centre has the capacity to attend to one hundred patients a day but only forty patients turn up, the capacity that is unused is lost forever. The unused capacity cannot be stored for a later time

Inseparability: Services are normally produced and consumed at the same time and in the same place. A medical examination is an example. The doctor cannot produce the service without the consumer being present. Further, the consumer is actually involved in the production process, answering the doctor's questions and describing his or her symptoms. Because of this inseparability feature, many people are involved concurrently in the production 
operations and the marketing effort in services firms. The chain of distribution in this case, is producer to the consumer. This implies that the producer sells his services directly to the consumer without an intermediary.

Heterogeneity: This means that service standard has the tendency to vary from time to time in the same firm. The services rendered to customers by a desk receptionist at a hotel tend to vary from customer to customer due to a variety of factors - the number of customers waiting to be served at a point in time, the behaviour of the customer being served, swings in the mood of the receptionist, etc. variability of service standard occur in the production and delivery of service largely because services are rendered by people who are to exercise discretion in the course of rendering them. Careful selection and training of service personnel, specification or detailed procedures for rendering service, supervision and use of technology are techniques used in controlling variability in service standards but the problem of service heterogeneity remains a critical feature of services (Inegbenebor, 2006).

Ownership: Lack of ownership is a basic difference between a service and a good. With goods, buyers have full use of the product and the benefits it provides. They can consume it, store it or sell it. But with a service a customer may only have personal access to it (e.g. a hotel room, an airline trip) for a limited time. Payment is usually for the use of, access to or hire of items.

Parasuraman, Zeithaml and Berry (1988) defined service quality as "global judgment or attitude relating to the superiority of the service". The superiority of the service is confirmed by what the service delivers, which is the outcome and is evaluated after the performance, and how the service is delivered, which is the process and is evaluated during delivery. Hoffman and Bateson (2006) defined service quality as an attitude formed by a long-term, overall evaluation of a firm's performance. This distinguishes the concept from customer satisfaction which is a short-term, transaction-specific measure (Hoffman $\&$ Bateson, 2006). The service quality process can be examined in terms of the gaps between management, employees' and customers' expectations and perceptions (Hoffman \& Bateson, 2006). According to Hoffman and Bateson (2006), service quality focuses on the customers' cumulative attitude towards the firm which is the result of a number of successful or unsuccessful service experiences.

According to Asubonteng, McCleary, and Swan (1996) what a service delivers is difficult to evaluate for any service, so consumers or customers rely on other measures of quality attributes associated with service delivery, as evidenced in the five generic dimensions of service quality. A survey of service theory seems to indicate that, clients will judge that quality is low if performance does not meet their expectation and that quality is high if performance exceeds their expectations. Asubonteng, et al (1996) observed that due to intense competition and the hostility of environmental factors, service quality has become the cornerstone marketing strategy for companies. This highlights how important improving service quality is to organisations for their survival and growth since 
it could help them tackle the challenges they face in a competitive market. This means that service-based companies are compelled to provide excellent services to their customers in order to have a sustainable competitive advantage. There is however, a need for these organisations to understand what service quality is in order to attain their objectives.

Many scholars agree with the summarised five dimensions of service quality; reliability, responsiveness, tangibles, empathy, assurance of (Zeithaml \& Bitner, 2000) and more recently the additional two interactive qualities namely: recognition and flexibility. These service dimensions are appreciated more depending on the individual characteristics, level of industry development and extent of competition. Specifically with respect to fast food outlets, service quality relates to quality of food, cleanliness, consistency, hospitality of staff, among others. Ogwo and Igwe (2012) found a positive relationship between service qualities and repurchase intention and willingness to recommend. Similarly, Ranaweera and Neely (2003) study on some moderating effects on the service-customer retention link in England showed that perception of service quality has a direct linear relationship with customer purchase intention. However, the study of Ogbeide and Agbadudu (2015) on determinants of brand equity, perceived value and revisit intention in the hotel industry revealed an insignificant relationship between perceived quality and revisit intention. Also, Cronin and Taylor (1992) study did not appear to have a significant effect on repurchase intention, while Lee and Feick (2001) and Gerpott, et al. (2001) study telecommunication industry in South Korea and Germany respectively showed that call rate, quality of core service, clarity of voice positively impact on customer patronage.

\section{Approaches to Measuring Service Quality}

The SERVQUAL model developed by Parasuraman et al. (1988) is the most frequently used measure of service quality. It measures the gaps between expected service and perceived service in different industries. The difference in perceptions and expectations is what determines the nature or quality of the service. A negative gap score is indicative that the perception scores are lower than the expectation scores and, therefore, the service does not meet and exceed a customer's expectations. SERVQUAL is based on five dimensions of service quality, namely, reliability (ability to perform the promised service dependably and accurately), responsiveness (willingness to help customers and prompt service), assurance (knowledge and courtesy of employees and their ability to gain trust and confidence), empathy (providing individualized attention to the customers) and tangibles (physical facilities, equipment and personnel appearance), and is operationalised in the form of two sections to measure customer expectations and perceptions. This measurement instrument is the most widely used tool for measuring service quality and its application continues to increase in different services settings, such as banks (Jabnoun and Tamimi, 2003), health (Arasli et al., 2008), education (Tan \& Kek, 2004), hospitality, travel and tourism (Mwanza \& Chingarande, 2013), and the call centre industry. 
Despite its wide usage the SERVQUAL model has been criticised by a number of researchers (Carman, 1990; Babakus \& Boller, 1992; Teas, 1994). Criticism was directed at the conceptual and operational aspects of the model, mostly its validity, reliability, operationalization of expectations, and dimensional structure. However, there is general agreement that SERVQUAL items are reliable predictors of overall service quality (Khan, 2003). Parasuraman et al. (1988) noted that even if it may be necessary to reword or modify some of the items, the SERVQUAL scale is applicable in a wide range of business services.

\section{Brand Image and Customer Patronage}

The American Marketing Association defined brand as any name, term, sign, symbol, or design, or combination of these that identifies the maker / seller of the product or service and differentiates it from competitors. Kotler (2000) contends that brand is a name, term, symbol, design or all the above, and is used to distinguish one's products and services from competitors. He observes that image is the way that public perceives the company or its product. Image is affected by many factors beyond the company's control. The consumer develops a set of brand beliefs about where each brand stands on each attribute. The set of beliefs about a brand make up brand image. The consumer's brand image will vary with his or her experiences as filtered by the effects of selective perception, selective distortion and selective retention. The level of brand awareness, image, identity, association, and reputation are very important in customer choice/patronage. Brand image is the perception about a brand as reflected by the brand as held in a consumer's memory (Kotler, Bouden \& Jane, 2006). Brand's image is a perceptual asset in the minds of stakeholders about a performance. It is built on the brand association with other brand identities. Marketing program/communication creates brand image that is used to influence consumer behaviour or patronage. Brand images are not only created by marketing program or communication but through direct experience, brand information, word of mouth, channel members, country of origin and place, and everything that has to do with the touch point between the brand and the customers. Ideally, for an organisation to achieve brand reputation it must have huge brand equity. Brand equity is the added value endowed to product and service which is reflected in how a consumer feels, thinks, and acts with respect to the brand (Ogwo \& Igwe, 2012).

The quality and quantity of brand promotion, image, and reputation can influence consumer patronage. Yi, Xiaoqin and Weiqing (2009) study found that corporate image positively relates to intention to buy and behavioural patronage. Similarly, Andreassen and Lindestad, (1998) found that good corporate image and reputation help to increase firm's sales, market share and to establish and maintain a loyal relationship with customer. A favourable corporate image can influence repeated patronage (Dick \& Basu, 1994). In a related study Chaudhuri and Holbrook (2001) and Boohene and Agyapong (2011) in Ghana showed that brand image and brand effect, combine, determine purchase loyalty and attitudinal loyalty. 


\section{Customer Value (Price) and Customer Patronage}

Customer value is an intangible factor which has significant role in influencing buying decisions. Customer value includes broadly psychometric variables like brand name, loyalty, satisfaction and referral opinions. Customer lifetime value is built over time by business firms and which also contributes to the individual perceptions of customers, augmenting their value. The concept of price or customer value has its origin in equity theory, which consists of the ratio of the consumers' outcome / input to that of the service provider outcome / input (Oliver \& Desarbo, 1988). Equity concept refers to customer evaluation of what is fair, right or deserved for the perceived cost of offering (Bolton \& Lemon, 1999), and a trade-off between the quality and benefits they perceive in the product relative to the sacrifice they pay (Monroe, 1991). Price is often used by consumers as an extrinsic product-quality cue (Teas \& Agarwal, 2000). It can be deduced that price or customer value is a subjective perception of trade-off between what a customer gives up (price, sacrifice) and what the consumer received (utility, quality, benefits). Many have used price as a measure of wealth, value and quality. Perceived cost includes monetary payments and non-monetary payment sacrifices such as time, consumption, energy, stress and risk experienced by a consumer. Apart from the consumers' direct evaluation of product attributes (product in-use value and redemption value) as suggested in Teas and Agarwal (2000), consumer often measures a company's ratio of outcome to inputs by making comparisons with its competitor's offerings.

Providing value to customers is critical. Price has been observed as an important variable affecting the acceptance, and even future patronage of fast food outlets. In supporting this, the studies of Woodruff (1997), Varki and Colgate (2001), and Mohammed (2008) found that the lower the charges, the more customer consumed and the higher the patronage. Chang and Width (1994) reported that price (customer-perceived value) has been found to be a major contributor to purchase and behavioural usage.

\section{Theoretical Framework}

Customer patronage has been associated with several factors. These factors include physical setting, business location, corporate identity and advanced inclination behaviour (Adiele \& Opara, 2015; Eze, Odigbo \& Ufot, 2015; Jere, Aderele \& Jere, 2014; Nwulu \& Asiegbu, 2015). Literature abounds on the antecedents of customer patronage including product service, quality, service environment, store choice, shopping experience, cost and merchandise value, location, merchandise and store atmosphere, access in store atmosphere and cross category product store assessment (Eze, et al., 2015). Jere (2014) suggests that a conceptualised notion of store patronage is augmented by attitudinal and behavioural intentions and they offer several benefits which include; functional or utilitarian benefits, hedonic benefits and psychological benefits (Kriesner \& Leeth, 2010). Other factors are hinged on behavioural measures (Ajzen, 1991; 
Nwulu \& Asiegbu, 2015). To better understand customer patronage behaviour researchers have made reference to several theories.

Prominent among them is the "Theory of Reasoned Action" (TRA), developed by Ajzen and Fishbein (1980). This theory asserts that "people have high degree of volitional control and make reasoned choices among alternatives" (Ajzen \& Fishbein, 1975). This research is guided by the theory of reasoned action (Ajzen \& Fishbein, 1980), which suggests that human behaviour is best predicted by an individual's stated intention to behave in a certain way. An individual's behavioural intention is a product of two factors: his/her attitude toward a given behaviour and his/her subjective norm (i.e., his/her perception of the desirability of the behaviours to important others). A greatly simplified view of buyer behaviour is offered in reasoned action theory which is operationalized in the extended Fishbein model (Ajzen \& Fishbein, 1980). This model has been the subject of extensive empirical validation and has shown impressive heuristic utility in consumer behaviour research (Sheppard et al., 1988). The basic theory is that a weighted combination of attitudes towards behaviour and subjective norms (attitudes imposed by referent groups) leads to intention which, in turn, precedes behaviour.

The theory of reasoned action (TORA) models decision processes where people have a high degree of volitional control and make reasoned choices among alternatives (Ajzen \& Fishbein, 1980). Martin Fishbein and Icek Ajzen developed and explicated TORA over a number of publications (Ajzen \& Fishbein, 1975; 1980). The theory is a development of Fishbein's (1967) theory of attitude and is known as the Fishbein-Ajzen behavioural intentions model, the I-B model and the extended model. Consumer researchers have applied the theory of reasoned action to a wide variety of behaviours over the years, including the consumption of automobiles, banking services, computer software, coupons, detergents, food choice, fast food restaurant choice and hotel choice. Sheppard et al. (1988) conducted two meta-analyses to investigate the effectiveness of the Fishbein and Ajzen model in marketing and social psychology research. They concluded that "the Fishbein and Ajzen model has strong predictive utility, even when utilised to investigate situations and activities that do not fall within the boundary conditions originally specified for the model". The extent to which the theory succeeds in predicting behavioural intention is usually evaluated by means of linear multiple regression analysis.

In proposing the theory of reasoned action, Ajzen and Fishbein (1980) argued that it provided a complete explanation of volitional control, and the addition of other variables would not significantly enhance the prediction of behavioural intention. Nevertheless, a number of additional components have been proposed, such as perceived moral obligation (Beck \& Ajzen, 1991), past behaviour (Bentler \& Speckart, 1979), habit (Tourila \& Pangborne, 1988), self-identity (Biddle et al., 1987) and retail characteristics and consumer lifestyle (Ogle et al., 2004). Perhaps the most significant of these proposed additions involves the influence of perceived behavioural control initially proposed by Ajzen (1985) in his theory of planned behaviour. However, this approach has been criticized by Fishbein and 
Stasson (1990) and Ajzen (1988), who acknowledge that problems associated with this extension to the model have yet to be extensively investigated. In the context of food choice behaviour Sparks et al. (1992) conclude that perceived control is likely to prove applicable to those classes of action where volitional choice is significantly impeded. Since the initial stages of this study indicated that volitional choice of using international fast food restaurants was not "significantly impeded", perceived behavioural control was not measured. A healthy debate about additions and modifications to the theory of reasoned action continues; other criticisms include limited applicability and conceptual problems. Nevertheless, the theory's basic proposals have received continuing, widespread empirical corroboration and support, having been successfully applied to a diverse range of behaviour.

The fast-food industry is one sector where the application of this theory has been found to be of immense relevance (Sheppard, Harwick \& Warshaw, 1988). The theory explains the functional relationship between attitude and subjective norm (i.e. attitude imposed by referent group) and that a person's behavioural intention is predicated on these two basic factors - attitude and subjective norm to maintain relationship (Ajzen \& Fishbien, 1975). Patronage behaviour can therefore be measured by myriads of factors including; patronage intention, shopping enjoyment, satisfaction, time spent, number of items bought, repeat purchase, money spent, share of wallet, patronage action and repeat purchase or re-patronage (Nwulu \& Asiegbu, 2015). However, this study selected three factors namely: service quality, brand image and customer value as determinants of customer patronage in fast food outlets.

\section{METHODOLOGY}

\section{Research Design}

In this study, survey research design was employed. A survey is a sociological procedure that uses mainly questions to collect information about the way people think or act. The survey was conducted through the use of questionnaire administration. The adoption of survey research design is due to its high flexibility of data collection, potential to build rapport, high degree of diversity of questions due to interaction. (Malhotra, Birks \& Wills, 2013). The primary data were obtained from the respondents through the use of questionnaire.

\section{Population of the Study and Sampling Technique}

This study seeks to find out the factors influencing customer patronage of fast food outlets in Benin City. The population of this study consists of customers that patronise fast food outlets in Benin Cit. Benin City is the capital of Edo State in South-West geopolitical zone of Nigeria. The choice of the City as the case study is informed by its strategic location as the gateway to the Western and other Southern parts of Nigeria. Also, the City is a home to majority of the ethnic 
groups in Nigeria. Fifty (50) respondents each was chosen in four fast food outlets namely: Mr. Biggs, Mat Ice, Kada Food and Omega Food in Benin City to have a sample size of two hundred (200). Convenience sampling, a non-probability sampling method was used in this study by selecting accessible customers of the aforementioned fast food outlets. The rationale for the adoption of convenience sampling is that it helps researcher to easily access and interacts with the respondents that filled the research instrument (questionnaire). Two hundred (200) copies of questionnaire were administered out of which 188 were used for data analyses. The return rate is $94 \%$.

\section{Model Specification}

Customer patronage serves as the dependent variable while the independent variables are service quality, brand image, customer value (price). The model is functionally expressed as:

CUSTPAT $=f(S E R Q U A L, B R I M A G E$, PRICE $)$

Therefore:

CUSTPAT $=\beta_{0}+\beta_{1}$ SERQUAL $+\beta_{2}$ BRIMAGE $+\beta_{3}$ PRICE $+\varepsilon$. Where:

CUSTPAT $=$ customer patronage

SERQUAL = service quality

$B R I M A G E=$ brand image

PRICE $=$ price

$\beta_{0}=$ constant

$\varepsilon=$ Error term

And a priori expectations: $\beta_{1}, \beta_{2}>0 ; \beta_{3}<0$

\section{VALIDITy AND ReLiability of INSTRUMENT}

In order to guarantee the validity of the instrument, a number of marketing experts especially the discussant of the proposal amended some items in the questionnaire. This helped to add value to the final copy of the questionnaire. Data collected from questionnaire administration were subjected to a reliability analysis to determine the reliability of the measures. The results are shown in the table below.

Reliability Test Using Cronbach's Alpha Method

Table 1

\begin{tabular}{|l|c|c|c|}
\hline \multicolumn{1}{|c|}{ Variables } & Item Number & Number of Items & $\begin{array}{c}\text { Cronbach's } \\
\text { Alpha Value }\end{array}$ \\
\hline Customer patronage & $6-11$ & 6 & 0.718 \\
\hline Service quality & $12-19$ & 8 & 0.836 \\
\hline Brand image & $20-22$ & 3 & 0.679 \\
\hline Price & $23-26$ & 4 & 0.714 \\
\hline
\end{tabular}


The above Table 1 shows that the reliability values for the variables are between 0.679 and 0.836 using Cronbach alpha method. It can be concluded that the instrument is reliable.

\section{Methods of Data Analysis}

The data that were generated from the use of structured questionnaire were analysed using descriptive statistics such as: simple percentage, mean, and frequency distribution. Also, inferential statistics such as Ordinary Least Square (OLS) regression analysis was used to estimate the relationship between the dependent variable (customer patronage) and the independent variables (service quality, brand image, customer value [price]) and test the related hypotheses accordingly. All tests of significance were carried out at 5\% level of significance. In addition, Statistical Package for Social Sciences (SPSS) version 22 software will be used for the analyses.

\section{DATA PRESENTATION, ANALYSES AND INTERPRETATION}

\section{Respondents' Demographics}

The respondents' demographics discussed in this section include: gender, marital status, age, educational qualification, and income per month of the respondents. The results are presented in Table 2 below.

Table 2

Gender of respondents

\begin{tabular}{|l|c|c|c|c|}
\hline \multicolumn{1}{|c|}{ Category } & Frequency & Percent & Valid Percent & $\begin{array}{c}\text { Cumulative } \\
\text { Percent }\end{array}$ \\
\hline Male & 75 & 39.9 & 39.9 & 39.9 \\
\hline Female & 113 & 60.1 & 60.1 & 100.0 \\
\hline Total & 188 & 100.0 & 100.0 & \\
\hline
\end{tabular}

Table 2 reveals that majority of the respondents sampled for this study are female which accounts for $60.1 \%$ while male accounts for $39.9 \%$. The result indicates that the margin between the genders of the respondents is relatively high.

Table 3

Marital status of respondents

\begin{tabular}{|l|c|c|c|c|}
\hline \multicolumn{1}{|c|}{ Category } & Frequency & Percent & Valid Percent & $\begin{array}{c}\text { Cumulative } \\
\text { Percent }\end{array}$ \\
\hline Single & 105 & 55.9 & 55.9 & 55.9 \\
\hline Married & 83 & 44.1 & 44.1 & 100.0 \\
\hline Total & 188 & 100.0 & 100.0 & \\
\hline
\end{tabular}


Table 3 reveals that majority of the respondents sampled for this study are single which accounts for $55.9 \%$ while married accounts for $44.1 \%$. The result indicates that the margin between the marital status of the respondents is moderate.

Table 4

Age of respondents

\begin{tabular}{|l|c|c|c|c|}
\hline \multicolumn{1}{|c|}{ Category } & Frequency & Percent & Valid Percent & $\begin{array}{c}\text { Cumulative } \\
\text { Percent }\end{array}$ \\
\hline Below 25 years & 25 & 13.3 & 13.3 & 13.3 \\
\hline 25-35 years & 77 & 41.0 & 41.0 & 54.3 \\
\hline 36-45 years & 78 & 41.5 & 41.5 & 95.7 \\
\hline $46-55$ years & 8 & 4.3 & 4.3 & 100.0 \\
\hline Total & 188 & 100.0 & 100.0 & \\
\hline
\end{tabular}

Table 4 revealed that 25 (13.3\%) of the respondents were less than 25 years old, 77 (41\%) of the respondents are within the age bracket of between 25-35 years, $78(41.5 \%)$ of the respondents are within the age bracket of between 36-45 years which constituted the majority of the respondents. Respondents between the age bracket of 46-55 years account for only $4.3 \%$. It can be concluded that majority of the customers that patronise fast food outlets are at their youthful age.

Table 5

Educational qualification of respondents

\begin{tabular}{|l|c|c|c|c|}
\hline \multicolumn{1}{|c|}{ Category } & Frequency & Percent & Valid Percent & $\begin{array}{c}\text { Cumulative } \\
\text { Percent }\end{array}$ \\
\hline Primary School & 1 & 0.5 & 0.5 & 0.5 \\
\hline SSCE & 34 & 18.1 & 18.1 & 18.6 \\
\hline ND/NCE & 52 & 27.7 & 27.7 & 46.3 \\
\hline HND/B.Sc & 62 & 33.0 & 33.0 & 79.3 \\
\hline Postgraduate & 39 & 20.7 & 20.7 & 100.0 \\
\hline Total & 188 & 100.0 & 100.0 & \\
\hline
\end{tabular}

Table 5 shows that only one respondent had primary school education which represents $0.5 \%$ of the respondents. 34 (18.1\%) of the respondents had secondary school certificate holders, 52 (27.7\%) of the respondents had National Diploma/ National Certificate of Education holders. 62 (33\%) of the respondents which is the largest group were the holders of Bachelor Degree / Higher National Diploma and 39 (20.7\%) of the respondents had Postgraduate Degree qualification. This shows that the questionnaire was filled by individuals which can be considered to be educated. 
Table 6

Income Level of Respondents

\begin{tabular}{|l|c|c|c|c|}
\hline \multicolumn{1}{|c|}{ Category (N) } & Frequency & Percent & Valid Percent & $\begin{array}{c}\text { Cumulative } \\
\text { Percent }\end{array}$ \\
\hline 10,000 \& below & 49 & 26.1 & 26.1 & 26.1 \\
\hline $10,001-50,000$ & 65 & 34.6 & 34.6 & 60.6 \\
\hline $50,001-100,000$ & 46 & 24.5 & 24.5 & 85.1 \\
\hline $100,001-200,000$ & 18 & 9.6 & 9.6 & 94.7 \\
\hline $200,001 \&$ above & 10 & 5.3 & 5.3 & 100.0 \\
\hline Total & 188 & 100.0 & 100.0 & \\
\hline
\end{tabular}

Table 6 shows that 49 (26.1\%) of the respondents earned between 10,000 and below per month, 65 (34.6\%) of the respondents earned between 10,001 and 50,000 per month, 46 (24.5\%) of the respondents earned between N 50,001 and 100,000 monthly, 18 (9.6\%) of the respondents earned between N 100,001 and 2000,000 monthly and 10 (5.3\%) of the respondents earned above 200,001 .

\section{Customer Patronage Variables in Fast Food Outlets}

The variables described in this section are customer patronage, service quality, brand image and price. The variables were measured on 5-point Likert scale of 5, 4, 3, 2, 1 for Strongly Agree, Agree, Neutral, Disagree and Strongly Disagree respectively. The items involved are: Item 6 to 26 in the questionnaire. The mean score was calculated by multiplying the frequency of each point by the weight and divided by the total number of respondents. The results are presented in the Tables 7 to 10 .

Table 7

Customer Patronage

\begin{tabular}{|l|l|c|c|}
\hline \multicolumn{1}{|c|}{ Statement } & MEAN & SD \\
\hline 6 & I regularly patronise this fast food outlet & 4.277 & 0.864 \\
\hline 7 & I intend to use this fast food outlet again & 4.101 & 0.934 \\
\hline 8 & I usually use this fast food outlet as my first choice & 4.053 & 1.068 \\
\hline 9 & I am satisfied with the patronise to this fast food outlet & 4.176 & 0.911 \\
\hline 10 & I would recommend this fast food outlet to others & 4.213 & 0.819 \\
\hline 11 & I will not switch to another fast food outlet the next time & 4.245 & 0.836 \\
\hline \multicolumn{2}{|l|}{ Overall mean and standard deviation } & 4.177 & 0.905 \\
\hline
\end{tabular}

Table 7 shows that majority of the respondents that fill the questionnaire agreed with all the items used in measuring customer patronage as the mean scores are above 3 point. The overall mean of 4.177 shows that the level of customer patronage among fast food outlets in Benin City is high. 
Table 8

Service Quality

\begin{tabular}{|c|l|c|c|}
\hline S/N & \multicolumn{1}{|c|}{ Statement } & MEAN & SD \\
\hline 12 & The fast food physical facilities are visually appealing & 4.037 & 1.026 \\
\hline 13 & The fast food employees are neat in appearance & 4.202 & 0.841 \\
\hline 14 & $\begin{array}{l}\text { When you have a problem, the fast food shows a sincere interest } \\
\text { in resolving it }\end{array}$ & 4.160 & 0.905 \\
\hline 15 & Employees of the fast food give prompt service & 3.878 & 1.114 \\
\hline 16 & Employees of the fast food are always willing to assist customers & 4.149 & 0.895 \\
\hline 17 & The fast food has operating hours convenient to all its customers & 4.149 & 0.846 \\
\hline 18 & The food quality of the fast food is good & 4.186 & 0.915 \\
\hline 19 & Serving ordered food accurately & 3.963 & 1.139 \\
\hline Overall mean and standard deviation & 4.090 & 0.960 \\
\hline
\end{tabular}

Table 8 shows that majority of the respondents that fill the questionnaire agreed with the items used in measuring service quality of the selected fast food outlets as the mean scores are above 3 point. The overall mean of 4.090 shows that the level of service quality among fast food outlets in Benin City is moderately high.

Table 9

Brand Image

\begin{tabular}{|l|l|c|c|}
\hline S/N & \multicolumn{1}{|c|}{ Statement } & MEAN & SD \\
\hline 20 & The fast food outfit is reputable & 4.080 & 0.865 \\
\hline 21 & The fast food name and image attract me to purchase & 4.202 & 0.960 \\
\hline 22 & The fast food outlet's image reflects my own personality & 4.106 & 0.970 \\
\hline \multicolumn{2}{|l|}{ Overall mean and standard deviation } & 4.129 & 0.931 \\
\hline
\end{tabular}

Table 9 shows that majority of the respondents that fill the questionnaire agreed with the items used in measuring the brand image of the selected fast food outlets as the mean scores are above 3 point. The overall mean of 4.129 shows that the perceived brand image of the selected fast food outlets in Benin City is high.

Table 10

Price

\begin{tabular}{|l|l|c|c|}
\hline S/N & \multicolumn{1}{|c|}{ Statement } & MEAN & SD \\
\hline 23 & Increases of price will not hinder me & 4.197 & 0.883 \\
\hline 24 & The fast food outlet provides good value for money & 2.452 & 1.180 \\
\hline 25 & Last purchase price affect brand patronage & 2.707 & 1.208 \\
\hline 26 & The value for money of a favourite food influences patronage & 2.601 & 1.204 \\
\hline \multicolumn{2}{|l|}{ Overall mean and standard deviation } & 2.989 & 1.119 \\
\hline
\end{tabular}

Table 10 shows that majority of the respondents agreed that increase of price will not hinder them. The reason for this may be because of the quality of services 
or food rendered by fast food. Some customers are ready to pay more to get quality service or food. The mean score for the statement is 4.197 which are higher than 3 point. However, Table 10 also shows that majority of the respondents that fill the questionnaire disagreed with the following items used in measuring the price: The fast food outlet provides good value for money $(\bar{X}=2.452$; $S D=1.180)$; Last purchase price affect brand patronage $(\bar{X}=2.707 ; S D=1.208)$; and the value for money of a favourite food influences patronage $(\bar{X}=2.601 ; S D=1.204)$. The overall mean of 2.989 shows that there is low perception on the price paid for services or foods in the selected fast food outlets in Benin City.

\section{Relationship AMONg CUSTOMER PATRONAGE, SERVice QUALITY, BRAND IMAGE AND PRICE}

The independent variables in this study include service quality, brand image and price while the dependent variable is customer patronage. In order to estimate the model specified, multiple regression was used. The results are shown below:

Table 11

Multiple regression for variables

\begin{tabular}{|l|c|c|c|c|}
\hline \multicolumn{1}{|c|}{ Variable } & Coefficient & Std. Error & t-Statistic & Prob. \\
\hline C & 1.058 & 0.193 & 5.490 & 0.000 \\
\hline Service quality & 0.496 & 0.049 & 10.073 & 0.000 \\
\hline Brand image & 0.301 & 0.050 & 6.001 & 0.000 \\
\hline Price & -0.061 & 0.033 & -1.851 & 0.066 \\
\hline R-squared & & 0.748 \\
\hline Adjusted R-squared & & 0.744 \\
\hline F-statistic & & 182.137 \\
\hline Prob(F-statistic) & & 2.000 \\
\hline Durbin-Watson stat & & 2.177 \\
\hline
\end{tabular}

The above regression results shows the relationships between customer patronage and factors influencing it namely: service quality, brand image and price. The coefficient of determination $\left(\mathrm{R}^{2}\right)$ value of 0.748 shows the extent to which the independent variables (service quality, brand image and price) explained the dependent variable which is customer patronage. The value of the Adjusted $\mathrm{R}^{2}$ of 0.744 shows that the independent variables (service quality, brand image and price), jointly explain $74.4 \%$ of the variation in the dependent variable - customer patronage. The result also reveals that service quality and brand image have positive and statistically significant relationship with customer patronage at $\rho<0.05$. However, price is not statistically significant because $p$ value is greater than $5 \%(\rho=0.066)$. The F-statistic of 182.137 is significant at $\rho<0.05$. This implies that there is a statistically significant relationship between customer patronage and the independent variables (service quality, brand image and price) as a group. The Durbin-Watson statistic of 2.177 reveals the absence of first order serial correlation. 


\section{HYPOTHESES TESTING}

The results in Table 11 is used to test the various hypotheses stated for this study. The hypotheses are stated in null form.

\section{Hypothesis One: Quality of service render by fast food outlets does not significantly affect customer patronage.}

The results $(\beta=0.496, t=10.073 ; p=0.000)$ in Table 11 show that there is a positive and significant relationship between service quality and customer patronage. Based on the result, we reject the null hypothesis. We therefore conclude that quality of service render by fast food outlets does significantly affect customer patronage.

\section{Hypothesis Two: There is no significant relationship between brand image and customer patronage of fast food outlets.}

The results $(\beta=0.301, t=6.001 ; p=0.000)$ in Table 12 show that there is a positive and significant relationship between brand image and customer patronage. Based on the result, we reject the null hypothesis. We therefore conclude that there is a significant relationship between brand image and customer patronage of fast food outlets.

\section{Hypothesis Three: There is no significant relationship between customer value (price) and customer patronage of fast food outlets.}

The results $(\beta=-0.061, t=-1.851 ; p=0.066)$ in Table 12 show that there is a negative and non-significant relationship between price and customer patronage. Based on the result, we do not reject the null hypothesis. It is therefore concluded that there is no significant relationship between customer value (price) and customer patronage of fast food outlets.

\section{Discussion of Findings}

Firstly, the result in Table 9 shows that majority of the respondents that filled the questionnaire agreed with the items used in measuring service quality of the selected fast food outlets as the mean scores are above 3 point. The overall mean of 4.090 shows that the level of service quality among fast food outlets in Benin City is moderately high. It is advisable that fast food outlets should consistently maintain high quality of service which can guarantee continuous patronage from target customers. This study found that the quality of service render by fast food outlet does positively and significantly affect customer patronage. The work of Adeleke and Aminu (2012) who found that service quality has a significant relationship with customer satisfaction and loyalty supported 
this finding. In similar vein, the studies of Payne and Holt (2001), Ball et al., (2004) and Aydin and Ozer, (2005) on the relationship between service quality and the worth placed on customers lend credence to this finding.

Secondly, the result in Table 10 shows that majority of the respondents that fill the questionnaire agreed with the items used in measuring the brand image of the selected fast food outlets as the mean scores are above 3 point. The overall mean of 4.129 shows that the perceived brand image of the selected fast food outlets in Benin City is high. This means that good brand image can promote customer patronage. The study reveals that brand image has significant relationship with customer patronage in the fast food outlet in Benin City. It is believed that image of a brand play a critical role in the patronage that the brand will attract. A positive brand image may lead to customer patronage and retention thereby improving market share and profitability. Furthermore, Chun and Davies (2006) argued that establishing positive brand image is a key success factor in customer patronage. Conclusively, brand image is very critical to any organisation in the long run and is a key determinant of customer patronage in fast food sector.

Finally, the result in Table 11 shows that majority of the respondents agreed that increase of price will not hinder them. The reason for this may be because of the quality of services or food rendered by fast food. Some customers are ready to pay more to get quality service or food. The mean score for the statement is 4.197 which is higher than 3 point. However, the overall mean of 2.989 shows that there is low perception on the price paid for services or foods in the selected fast food outlets in Benin City. From the regression results, it was found that price does not significantly influence customer patronage. Also the relationship between them is negative implying that the higher the price, the lower the patronage level, all things being equal. This finding contradict outcomes of the work of Varki and Colgate (2001) who found that significant relationship exist between price and the worth place on customers.

\section{CONCLUSION AND RECOMMENDATIONS}

The main objective of this study was to examine the factors determining customer patronage of fast food outlets in Benin City. The study specifically determined whether the quality of service render by fast food outlet significantly affect customer patronage, ascertained the influence of brand image on customer patronage of fast food outlets and examined the relationship between customer value (price) and customer patronage of fast food outlets.

Survey research design was adopted for this study. In this study, customer patronage is the dependent variable while the independent variables include service quality, brand image and price. The population includes all customers that patronise fast food outlets in Benin City, Edo State. Fifty (50) respondents each were chosen in four fast food outlets namely: Mr. Biggs, Mat Ice, Kada Food and Omega Food to have a sample size of two hundred (200) out of which 188 questionnaires were found useable, amounting to $94 \%$. The questionnaires were 
distributed using convenience sampling technique to the customers of the selected fast food outlets. Both descriptive and inferential statistics were used in analysing the data obtained. The descriptive statistics used include frequency distribution, mean and standard deviation. Multiple regressions were used as an inferential statistics to test the research hypotheses. All hypotheses were tested at 5\% level of significance. Statistical Package for Social Science (SPSS 22.0) software was used for all the analyses. The study found that the quality of service render by fast food outlet does positively and significantly affect customer patronage and that there is positive and significant relationship between brand image and customer patronage of fast food outlets. Based on the empirical and theoretical finding of this study, the following recommendations were made:

1. Fast food outlets should sustain and improve on the factors that have been found to be statistically significant. These factors are service quality and brand image. Improving on the quality of service rendered and the brand image by fast food outlets will make them to be attractive to both present and potential customers.

2. Though price can serve as a symbol of prestige, to increase market share and have wider coverage, it is suggested that affordable prices should be set for their menus.

3. Finally, it is suggested that future studies increase the number of fast food outlets and possibly the sample size that will be taken from each. It is also suggested that more variables should be included in future studies.

\section{REFERENCES}

1. Adeleke, A., \& Aminu, S. (2012). Determinants of customer loyalty in Nigeria GSM's market. International Journal of Business and Social Science 3(14), 209-222.

2. Adeniyi, S. (2004, November 10). Soft drinks in Nigeria are dangerous to public health. Nigerian Tribune.

3. Adeniyi, S. (2005, January 27). Nigeria is fast becoming a junk food nation. Nigerian Tribune.

4. Adiele, K. C., \& Opara, B. C. (2014). Analysis of corporate identity on customer patronage of banks in Nigeria. International Review of Management and Business Research, 3(4), 1809.

5. Ajala, J. A. (2006). Understanding food and nutrition. Ibadan: MayBest Publications.

6. Ajzen, I. (1991). From intentions to actions: A theory of planned behaviour. In Kuhl, J. \& Beckmann J. (eds.) Action-control: From commitment to behaviour. Springer, Heidelberg.

7. Ajzen, I. (1988). Attitudes personality and behaviour. Open University, Milton Keynes.

8. Ajzen, I., \& Fishbein, M. A. (1980). Understanding attitudes and predicting social behaviour. Prentice-Hall, Englewood Cliffs, NJ.

9. Aladelokun, D. (2006, June 24). Health freedom activists warn of the dire consequences of abandoning natural foods. Saturday Punch.

10. Andreassen, T. W., \& Lindestad, B. (1998). Customer loyalty and complex services. International Journal of Service Industry Management, 9(1), 7-23. http://dx.doi.org/10.1108/09564239810199923 
11. Arasli, H., Ekiz, E. H., \& Katircioglu, S. T. (2008). Gearing service quality into public and private hospitals in small islands: Empirical evidence from Cyprus. International Journal of Health Care Quality Assurance, 21(1), 8-23.

12. Asubonteng, P., McCleary, K. J., \& Swan, J. E. (1996). SERVQUAL revisited: A critical review of service quality. The Journal of Services Marketing, 10(6), 62-81.

13. Aydin, S., \& Ozer, G. (2005). The analysis of antecedents of customer loyalty in the Turkish mobile telecommunication market. European Journal of Marketing, 39, 910-925.

14. Babakus, E., \& Boller, G. W. (1992). An empirical assessment of the SERVQUAL scale. Journal of Business Research, 24(3), 253-268.

15. Ball, D., Coelho, P., \& Machas, A. (2004). The role of communication and trust in explaining customer loyalty - An extension to the ECSI model. European Journal of Marketing, 38(10), 1272-1293.

16. Beck, L., \& Ajzen, I. (1991). Predicting dishonest actions using the theory of planned behaviour. Journal of Research in Personality, 25, 285-301.

17. Bentler, P. M., \& Speckart, G. (1979). Models of attitude-behaviour relations. Psychological Review, 86, 452-464.

18. Biddle, B. J., Bank, B. J., \& Slavings, R. L. (1987) Norms, preferences, identities and retention decisions. Social Psychology Quarterly, 50, 322-337.

19. Bolton, R. N., \& Lemon K. N. (1999). A dynamic model of customer usage of services: usage as antecedents and consequences of satisfaction. Journal of Marketing Research, 36, 171-186. http://dx.doi.org/10.2307/3152091

20. Boohene, R., \& Agyapong, G. K. Q. (2011). Analysis of the antecedents of customer loyalty of telecommunication industry in Ghana: The Case of Vodafone (Ghana). International Business Research, 4(1), 229-240. Retrieved from http://www.ccsenet.org/journal/index.php/ibr/articledownload/8813/6459

21. Carman, J. M. (1990). Consumer perceptions of service quality: An assessment of the SERVQUAL dimensions. Journal of Retailing, 66(2), 27-45.

22. Chang, T. Z., \& Width, A. R. (1994). Price product information, and purchase intention: An empirical study. Journal of the academy of marketing sciences, 22, 16-27. http://dx.doi.org/10.1177/0092070394221002

23. Chaudhuri, A. M., \& Holbrook, M. B. (2001). The Chain of effect from Brand Trust and Brand Affect to Brand Performance: The role of brand loyalty. Journal of Marketing, 65(April), 81-93. http://dx.doi.org/10.1509/jmkg.65.2.81.18255

24. Chun, R., \& Davies, G. (2006). The influence of corporate character on customers \& employees: exploring similarities and differences. Journal of the Academy of Marketing Science, 34(2), 138-146.

25. Cronin, J. J., \& Taylor, S. A. (1992). Measuring Service Quality - a reexamination and intention. Journal of Marketing, 56(3), 55-68. http://dx.doi. org/10.2307/1252296

26. Czepiel, J. A., \& Culmore, K. (1987). Exploring the concept of loyalty in services. Chicago: American Marketing Association.

27. Dick, A., \& Basu, K. (1994). Customer loyalty: Toward and integrated conceptual framework. Journal of Academy of Marketing Services, 22(2), 99-113. http://dx.doi. org/10.1177/0092070394222001

28. Drucker, P. F. (1973). Management: Tasks, Responsibilities, practices. New York, NY: Harper and Row.

29. Eze, F. J., Odigbo, B. E., \& Ufot, J. A. (2015). The correlation between business location and consumers' patronage: Implications for business policy decisions. British Journal of Economics, Management \& Trade, 8(4), 294-304. 
30. Fishbein, M., \& Stasson, M. (1990). The role of desires, self-predictions and perceived control in the prediction of training session attendance. Journal of Applied Social Psychology, 20, 173-198.

31. Gerpott, Rams, \& Schindler, T. J., Rams, W., \& Schindler, A. (2001). Customer retention, loyalty, and satisfaction in the German mobile cellular telecommunication market. Telecommunication Policy, 25, 249-269.

32. Hoffman, K. D., \& Bateson, J. E. G. (2006). Services marketing: Concepts, strategies, and cases. $3^{\text {rd }}$ ed. Ohio: Thomson South-Western.

33. Ibrahim, Y., \& Vignali, C. (2005). Predicting consumer patronage behaviour in the Egyptian fast food business. Innovative Marketing, 1(2), 60-76.

34. Ijewere, A. A. (2008). Marketing theory and practice: A Nigerian perspective, $3^{\text {rd }}$ ed. Benin City: UNIBEN Press.

35. Inegbenebor, A. U. (2006). Elements of service operations. In A. U. Inegbenebor (ed.) The Fundamentals of Entrepreneurship. Benin City: Malthouse Press Limited.

36. Jabnoun, N., \& Al-Tamimi, H. A. H. (2003). Measuring perceived service quality at UAE commercial banks. International Journal of Quality and Reliability Management, 20(4), 458-472.

37. Jere, M. G., Aderele, B. A., \& Jere, A. (2014). Exploring factors that influence store patronage amongst low income consumers in Cape town, South Africa. Mediterranean Journal of Social Sciences, 5(20), 152.

38. Jones, P., Hillier, D., Shears, P. and Clarke-Hill, C. (2002). Customer perceptions of services brands: A case study of the three major fast food retailers in the UK. Management Research News, 25 (6/7), 41-49.

39. Khan, M. (2003). ECOSERV: Ecotourists' quality expectations. Annals of Tourism Research, 30(1), 109-124.

40. Konwea, P. E. (2012). Increasing trends in the consumption of fast foods in Nigeria. International Journal of Arts and Humanities, 1(1), 95-109.

41. Kotler, P. (2000). Marketing management. The millennium edition, Upper Saddle River, Prentice Hall.

42. Kotler, P. (2003). Marketing management. (11 ${ }^{\text {th }}$ ed.) New Delhi, India: PrenticeHall of India.

43. Kotler, P., \& Keller K. (2006). Marketing management (12 ${ }^{\text {th }}$ ed). U.S.A, New Jersey: Pearson Prentice Hall.

44. Kotler, P., Bouden, J. T., \& Jane, M. C. (2006). Marketing for hospitality and tourism $\left(4^{\text {th }}\right.$ ed.). U.S.A. Pearson International.

45. Kriesner, T. J., \& Leeth, J. D. (2010). Hedonic wage equilibrium: Theory, evidence and policy. London: Now Publishers Inc.

46. Lee, J., \& Feick, L. (2001). The Impact of switching cost on the customer satisfaction - loyalty link: Mobile phone service in France. Journal of Service Marketing, 15, 35-48. http://dx.doi.org/10.1108/08876040110381463

47. Malhotra, N. K., Birks, D. F., \& Wills, P. A. (2013). Essentials of marketing research. Harlow: Pearson.

48. Mohammed, I. S. (2008). The analysis of customer loyalty in Bangladeshi mobile phone operator industry. Independent University, Bangladesh. Retrieved from http:/ /www.wbiconpro.com/501-Sohel pdf

49. Monroe, K. B. (1991). A test of services marketing theory: Consumer information acquisition activities. Journal of Services Marketing, 55, 10-25.

50. Morden, A. R. (1991). Elements of Marketing ( $2^{\text {nd }}$ ed.), Greet Britain: Educational Low-Priced Books Scheme. 
51. Mwanza, C., Chingarande, G. R. (2013). A tourist's evaluation of the quality of service delivered by the front offices: A case of the Namibian wildlife resorts. International Journal of Advanced Research in Management and Social Science, 2(6), $10-20$.

52. Nwulu, C. S., Asiegbu, I. F. (2015). Advancement inclination behaviours and university academic staff patronage of deposit money banks in Port Harcourt. International Journal of Research in Business Studies and Management, 2(6), 94-104.

53. Ogbeide, D. O., \& Agbadudu, J.E. (2015). Determinants of brand equity, perceived value and revisit intention in the hotel industry. Management Sciences Review, 6(1\&2), 264-284.

54. Ogle, J. P., Hyllegard, K. H. \& Dunbar, B. H. (2004). Predicting patronage behaviour in sustainable retail environment: Adding retail characteristics and consumer lifestyle orientation to the belief-attitude-behaviour intention model. Environment and Behaviour, 36(5), 717-741.

55. Ogwo, E. O. \& Igwe, S. R. (2012). Some key factors influencing attitudes to patronage of GSM services: The Nigerian experience. International Journal of Business Management, 7(18), 83-91.

56. Oliva, T. A., Oliver, R. L., \& MacMilan, I. C. (1992). A catastrophe model for developing service satisfaction strategies. Journal of Marketing, 56, 183-193. http://dx.doi.org/10.2307/1252298

57. Oliver, R. L., \& Desarbo, W. S. (1988). Response determinants in satisfaction judgements. Journal of Consumer Research, 14, 495-508.

58. Parasuraman, A., Zeithaml, V. A. \& Berry, L. L. (1988). SERVQUAL: A multi-item scale for measuring consumer perceptions of service quality. Journal of Retailing, 64(1), 12-40.

59. Payne A., \& Holt, S. (2001): Diagnosing customer value: Integrating the value process and relationship marketing. British Journal of Management, 12, 159-182.

60. Peter, D. (1998). Marketing management and strategy, $2^{\text {nd }}$ ed., England: Pearson Education Limited.

61. Ranaweera, C., \& Neely, A. (2003). Some moderating effects on the service quality - customer retention. International Journal of Operation and Production Management, 2(23), 230-247. http://dx.doi.org/10.1108/01443570310458474

62. Salami, C. G. E., \& Ajobo, R. T. (2012). Consumer perceptions about fast food restaurants in Asaba. Global Journal of Management and Business Research, 12(1), $75-81$.

63. Schiffman, L. G. \& Kanuk, L. L. (2009). Consumer behaviour. New Delhi: Prentice Hall of Indian.

64. Schlosser, E. (2001). Fast food nation: The dark side of the all-American meal. Boston: Houghton Miltlins.

65. Schlosser, E. (2002). Fast food nation: what the all-American meal is doing to the world. London, Penguin Group.

66. Sheppard, B. H., Hartwick, J., \& Warshaw, P. R. (1988). The theory of reasoned action: A meta-analysis of past research with recommendations for modifications and future research. Journal of Consumer Research, 15(3), 325-343.

67. Sheppard, B. H., Hartwick, J. Warshaw, P. R. (1988). The Theory of Reasoned Action: A Meta-Analysis of Past Research with Recommendations for Modifications and Future Research. Journal of Consumer Research, 15, 325-343.

68. Stanton, A. E., Etzel, C. A., Walker, P. O. (1998). Marketing principles and practice. New York: McGraw House. 
69. Tafamel, A. E., \& Oshodin, E. A. (2015). Customer repurchase intentions, selfimage and brand for mobile phones users in Benin City, Nigeria. Management Sciences Review, 6(1\&2), 121-146.

70. Tan, K. C., \& Kek, S. W. (2004). Service quality in higher education using an enhanced servqual approach. Quality in Higher Education, 12(1), 111-124.

71. Teas, R. K., \& Agarwal, S. (2000). The effects of Extrinsic Product cues on consumers' perception of quality, sacrifice and value. Journal of the Academy of Marketing Science, 28, 278-291. http://dx.doi.org/10.1177/0092070300282008

72. Teas, R. K. (1994). Expectations: A comparison standard in measuring service quality: An assessment of a reassessment. Journal of Marketing, 58(1), 132-139.

73. Tourila, H., Pangborn, R. M. (1988). Prediction of reported consumption of selected fat-containing foods. Appetite, 11, 81-95.

74. Varki S., Colgate M. (2001). The role of price perceptions in an integrated model of behavioural intentions. Journal of Service Research, 3(3), 232-240.

75. Woodruff, R. B. (1997). Customer value: The next source of competitive advantage. Journal of Academy of Marketing Science, 25(2), 139-153. http://dx.doi. org/10.1007/BF02894350

76. Yi, H., Xiaoqin Y., \& Weiqing Z. (2009). How to promote customer Loyalty of Chinese Mobile Operators: Case study of China Mobile. Master of Business Administration, University of Blekinge Tekniska Högskola BTH.

77. Zeithaml, V. A., Bitner M. J. (2000). Services marketing, integrating customer focus: $A$ cross the firm ( $2^{\text {nd }}$ ed.). U.S.A.: McGraw Hill, Irwin. 